\title{
Nitrate Dependent Anaerobic Acetylene-reduction and Nitrogen-fixation by Soybean Bacteroids
}

\author{
By J. RIGAUD,* F. J. BERGERSEN, G. L. TURNER AND \\ R. M. DANIEL \\ Division of Plant Industry, Commonwealth Scientific and Industrial Research \\ Organization, Canberra, 260 I, Australia
}

(Received 22 January 1973)

SUMMARY

Bacteroids isolated from nodules produced by one strain of Rhizobium japonicum (CC705) had strong nitrate-reducing activity and reduced $\mathrm{C}_{2} \mathrm{H}_{2}$ to $\mathrm{C}_{2} \mathrm{H}_{4}$ and $\mathrm{N}_{2}$ to $\mathrm{NH}_{3}$ anaerobically with nitrate. Bacteroids of another strain (CBI809) were much less active nitrate reducers and reduced little $\mathrm{C}_{2} \mathrm{H}_{2}$ anaerobically. Nitrite, which accumulated in the medium in anaerobic assays, was an inhibitor of $\mathrm{C}_{2} \mathrm{H}_{2}$ reduction in both aerobic and anaerobic conditions. Succinate, at about $25 \mathrm{~mm}$, stimulated both nitrate reduction and $\mathrm{C}_{2} \mathrm{H}_{2}$ reduction under aerobic conditions. Glucose stimulated $\mathrm{C}_{2} \mathrm{H}_{2}$ reduction up to $120 \mathrm{~mm}$ but nitrate reduction was inhibited in the presence of glucose. In terms of electrons transferred, the aerobic pathway appeared to be about 2.5 times more efficient than the anaerobic pathway in supporting nitrogenase activity of $\mathrm{CC} 705$ bacteroids.

\section{INTRODUCTION}

The utilization of nitrate for respiration by some strains of Rhizobium japonicum under low $\mathrm{O}_{2}$ tension was suggested by Murphy \& Elkan ( 1965). Daniel \& Appleby (1972) reported that $R$. japonicum (strain CC705) grew anaerobically with nitrate; they also found high levels of nitrate reductase activity in bacteroids isolated from soybean nodules as had been reported previously (Cheniae \& Evans, 1960; Bergersen, I96I). $\mathrm{N}_{2}$ fixation by intact nodules and by bacteroid suspensions is normally aerobic (Bergersen \& Turner, 1967), but nitrate respiration might produce ATP for the support of $\mathrm{N}_{2}$ fixation by soybean nodule bacteroids under anaerobic conditions. We now report anaerobic, nitrate-dependent reduction of $\mathrm{C}_{2} \mathrm{H}_{2}$ to $\mathrm{C}_{2} \mathrm{H}_{4}$ and of $\mathrm{N}_{2}$ to $\mathrm{NH}_{3}$ by bacteroid suspensions. The effects of substrate and nitrate concentrations were also investigated and comparisons were made between two strains of Rhizobium japonicum and between nitrate-dependent and $\mathrm{O}_{2}$-dependent reactions.

\section{METHODS}

Nodules. Soybeans (Glycine max Merr., cv. Lincoln), inoculated with Rhizobium japonicum strain CBI 809 or CC705 (syn. Wisconsin 505), were grown as previously described (Bergersen, I970) and collected about 35 days after sowing (nodule age 28 to 29 days), when nitrate reductase activity in the bacteroids was high; it declined in older nodules (cf. Bergersen, I96I).

Bacteroid suspensions. Nodules (about 20 to $40 \mathrm{~g}$ fresh wt) were homogenized in a Sorvall Omni-mixer under argon, in $100 \mathrm{ml}$ potassium phosphate buffer (O. $1 \mathrm{M}, \mathrm{pH} 7.0$ ) containing sodium ascorbate ( $0.2 \mathrm{M})$ and polyvinyl pyrrolidone $(50 \mathrm{~g})$ and the homogenate filtered, as

\footnotetext{
* Present address: Faculté des Sciences, Laboratoire de Biologie Végétale, 06-034 Nice-Cedex, France.
} 
described previously (Bergersen \& Turner, I970, I973). The filtrate was centrifuged and the sedimented bacteroids were washed twice in phosphate buffer $(25 \mathrm{~mm}, \mathrm{pH} 7 \cdot 4)$ and their dry weight recorded.

Assays of nitrogenase activity. In most cases, activity was measured by $\mathrm{C}_{2} \mathrm{H}_{2}$ reduction (Hardy, Holsten, Jackson \& Burns, 1968). In anaerobic conditions the assays were done in duplicate in rubber-capped glass vials ( $13.5 \mathrm{ml}$ capacity) containing, in $5 \mathrm{ml}$ of phosphate buffer ( $25 \mathrm{~mm}, \mathrm{pH} 7 \cdot 4)$, glucose or sodium succinate as substrate at various concentrations, and $\mathrm{KNO}_{3}(8 \mathrm{~mm})$. The gas phase contained $25 \%(\mathrm{v} / \mathrm{v}) \mathrm{C}_{2} \mathrm{H}_{2}$ or $70 \%{ }^{15} \mathrm{~N}_{2}$ in argon. The reactions were started by the injection of bacteroids ( 40 to $50 \mathrm{mg}$ dry wt/assay) and the vials were agitated on a reciprocating shaker at 100 c.p.m. at $30^{\circ} \mathrm{C}$. The reactions were terminated by the injection of I $\mathrm{ml}$ of $2.5 \mathrm{~N}-\mathrm{HCl}$ containing $\mathrm{I} \%(\mathrm{w} / \mathrm{v})$ sulphanilamide.

In aerobic conditions, Warburg vessels ( $15 \mathrm{ml}$ capacity) with rubber-capped sidearms were used, containing in $2 \mathrm{ml}$ of phosphate buffer $(25 \mathrm{mM}, \mathrm{pH} 7 \cdot 4)$, sodium succinate ( $50 \mathrm{mM})$ unless otherwise stated, and approximately $20 \mathrm{mg}$ (dry wt) of bacteroids. The gas phase contained $5 \%(\mathrm{v} / \mathrm{v}) \mathrm{O}_{2}$ and $25 \%(\mathrm{v} / \mathrm{v}) \mathrm{C}_{2} \mathrm{H}_{2}$ or $70 \%{ }^{15} \mathrm{~N}_{2}$ in argon and the final pressure was $700 \mathrm{mmHg}$. Flasks were shaken at $\mathrm{I} 50$ c.p.m. at $30{ }^{\circ} \mathrm{C}$; these conditions were critical for optimum activity in aerobic assays with $\mathrm{CC7} 705$ bacteroids. Reactions (in duplicate) were started by tipping the bacteroids from the sidearms and were terminated by the injection of $0.3 \mathrm{ml}$ of $10 \%(\mathrm{w} / \mathrm{v})$ trichloroacetic acid.

$\mathrm{C}_{2} \mathrm{H}_{2}$ reduction was measured by analysing $200 \mu \mathrm{l}$ samples of gas from reaction vessels as described previously (Bergersen, 1970). $\mathrm{N}_{2}$ fixation was measured by determining the ${ }^{15} \mathrm{~N}$ content of $\mathrm{NH}_{3}$, recovered by steam distillation of the reaction mixture supernatants, using $50 \mu \mathrm{g}$ of unlabelled $\mathrm{NH}_{3}-\mathrm{N}$ as a carrier (Bergersen \& Turner, I968) and saturated $\mathrm{Na}$-borate, $\mathrm{pH}$ i0.5. In all experiments, there was little variability between duplicates (e.g. Table I) and in the Figures only mean values are shown.

Determination of nitrite. The colorimetric method of Nicholas \& Nason (1957) was used for the determination of nitrite in supernatants after centrifugation of reaction mixtures.

Measurement of $\mathrm{O}_{2}$ uptake. Aerobic respiration was measured by analysis of gas samples collected from reaction vessels, using an Atlas M 86 mass spectrometer, calibrated for the various gases.

RESULTS

The relationship between anaerobic $\mathrm{C}_{2} \mathrm{H}_{2}$ reduction and nitrate reductase activity

The results of a typical experiment with $\mathrm{CC} 705$ bacteroids are given in Fig. I. Acetylene reduction was stimulated by succinate and glucose and the rates declined after to to $15 \mathrm{~min}$. Anaerobic $\mathrm{C}_{2} \mathrm{H}_{2}$ reduction was absolutely dependent upon the presence of nitrate and the rate increased with increasing nitrate concentrations up to $4 \mathrm{~mm}$ (Fig. 2). The time course of nitrate reduction was different from that of $\mathrm{C}_{2} \mathrm{H}_{2}$ reduction; there was an initial lag, followed by a period in which the rates were constant. It also appeared that the rates of nitrate reduction with different substrates were not related to rates of $\mathrm{C}_{2} \mathrm{H}_{2}$ reduction, since glucose $(60 \mathrm{~mm})$ produced the highest rate of $\mathrm{C}_{2} \mathrm{H}_{2}$ reduction, but the lowest rate of nitrate reduction. Also, $\mathrm{C}_{2} \mathrm{H}_{2}$ reduction was highest in each treatment in the first 10 min when nitrate reduction rates were lowest. There was substantial endogenous $\mathrm{C}_{2} \mathrm{H}_{2}$ reduction and nitrate reduction (Fig. 3).

Identical experiments with CBI809 bacteroid suspensions produced little activity in either $\mathrm{C}_{2} \mathrm{H}_{2}$ reduction or nitrate reduction (for example in $30 \mathrm{~min} 0.3 \mathrm{nmol} \mathrm{C}_{2} \mathrm{H}_{4} \mathrm{mg}^{-1}$ and $8.4 \mathrm{nmol}$ $\mathrm{NO}_{2}{ }^{-} \mathrm{mg}^{-1}$ were produced), although aerobic $\mathrm{C}_{2} \mathrm{H}_{2}$ reduction was very active $(86.7 \mathrm{nmol}$ $\mathrm{C}_{2} \mathrm{H}_{4} \mathrm{mg}^{-1}$ in $30 \mathrm{~min}$ ). 

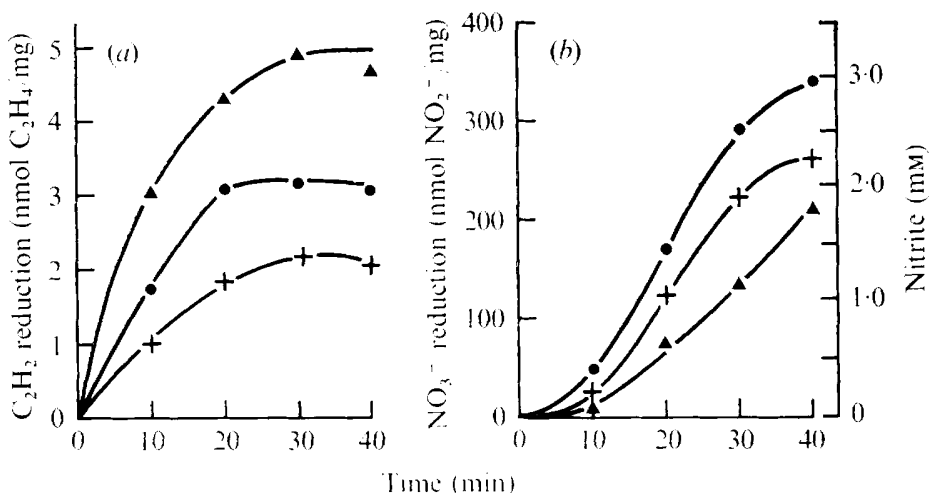

Fig. I. Time course of $\mathrm{C}_{2} \mathrm{H}_{2}$ reduction (a) and nitrate reduction $(b)$ by bacteroid suspensions, in anaerobic conditions. Incubation mixtures $(5 \mathrm{ml})$ contained $\mathrm{KNO}_{3}(8 \mathrm{~mm})$, bacteroids, strain CC705 (42 mg dry wt). The substrate was glucose (A-_ $\mathbf{\Delta}, 60 \mathrm{~mm})$, succinate nil $(+-+)$. The shaking rate was 100 c.p.m. at 30 C. For other details see text.

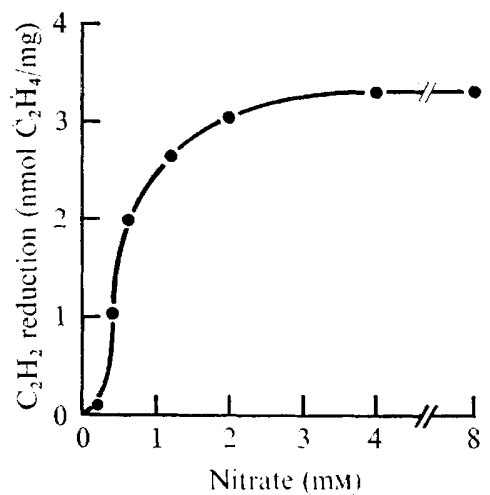

Fig. 2. The effect of nitrate concentration upon $\mathrm{C}_{2} \mathrm{H}_{2}$ reduction by bacteroid suspensions, in anaerobic conditions. Incubation mixtures $(5 \mathrm{ml})$ contained glucose $(50 \mathrm{~mm}), \mathrm{KNO}_{3}(0 \cdot 2$ to $8 \mathrm{~mm})$, bacteroids strain $\operatorname{CC} 705$ ( $45 \mathrm{mg}$ dry wt). Assayed for $10 \mathrm{~min}$ at $30 \mathrm{C}$ with shaking.
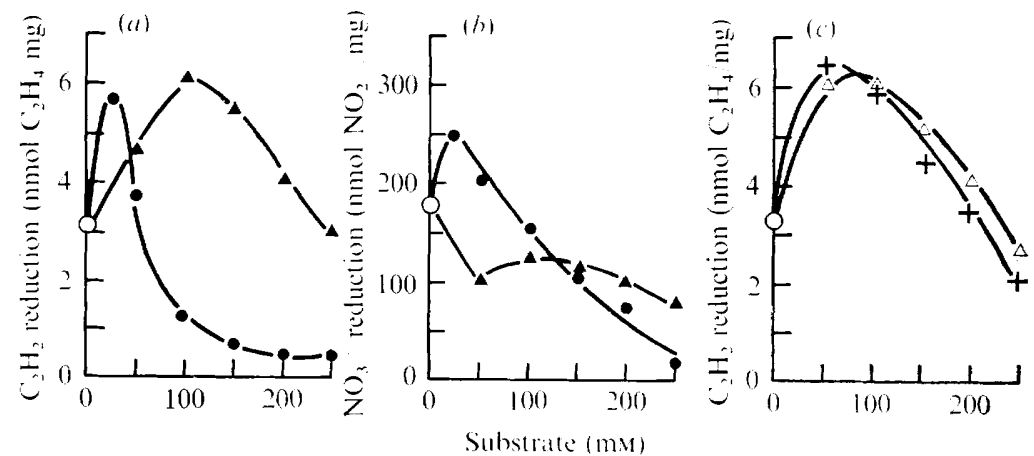

Fig. 3. The effect of glucose and sodium-succinate upon $\mathrm{C}_{2} \mathrm{H}_{2}$ reduction $(a, c)$ and nitrate reduction (b) by bacteroid suspensions, in anaerobic conditions. Bacteroids were resuspended in phosphate buffer, $25 \mathrm{~mm}, \mathrm{pH}_{7 \cdot 4}(a, b)$ and substrates were sodium-succinate $(-\infty)$ or glucose $(\boldsymbol{\Delta}-\boldsymbol{\Delta})$. Bacteroids resuspended $(c)$ in $15 \%(\mathrm{w} / \mathrm{v})$ dextran $40(\Delta-\Delta)$, and in $30 \%(\mathrm{w} / \mathrm{v})$ dextran 40 $(+-+)$ in the same buffer with glucose as substrate. Assayed at 30 C for 20 min with shaking. 


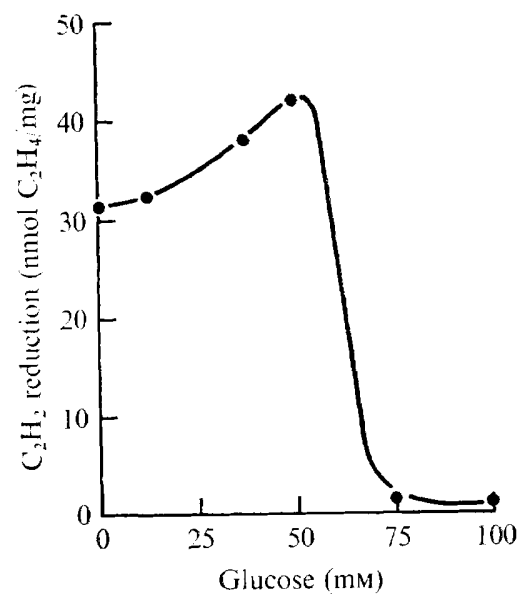

Fig. 4. Effect of glucose upon $\mathrm{C}_{2} \mathrm{H}_{2}$ reduction by bacteroid suspensions in aerobic conditions. Incubation mixtures $(2 \mathrm{ml})$ contained sodium-succinate $(50 \mathrm{~mm})$, glucose (o to $100 \mathrm{~mm})$, bacteroids strain $\mathrm{CC} 705$ (22 $\mathrm{mg}$ dry wt). Assayed for $30 \mathrm{~min}$ at $30 \mathrm{C}$ with shaking.
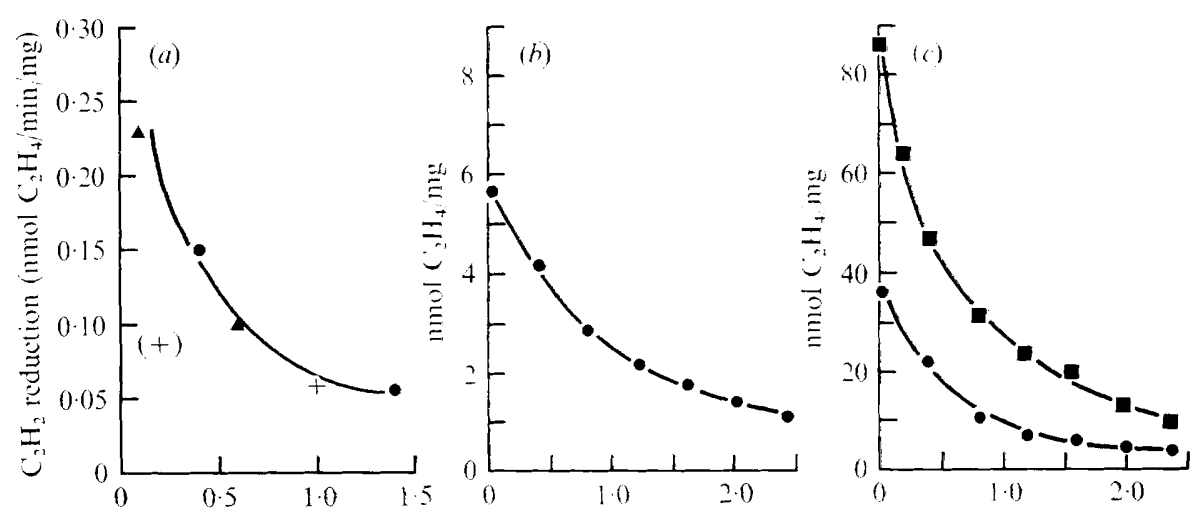

Final nitrite concentration ( $\mathrm{mm}$ )

Fig. 5. Inhibitory effects of nitrite upon $\mathrm{C}_{2} \mathrm{H}_{2}$ reduction by bacteroid suspensions. (a) Acetylenereduction velocities at $\mathrm{IO}$ and $20 \mathrm{~min}$ were derived from tangents drawn to the curves of Fig. I. These rates are plotted as a function of nitrite concentration at those times. , Succinate; $\Delta-\mathbf{A}$, glucose; +- + without additions. (b) The effect of nitrite added to anaerobic incubation mixtures $(5 \mathrm{ml})$ containing glucese $(50 \mathrm{~mm}), \mathrm{KNO}_{3}(8 \mathrm{~mm})$ and $17 \mathrm{mg}$ (dry wt) of cc705 bacteroids. The vessels were shaken at $30 \mathrm{C}$ for $30 \mathrm{~min}$. The nitrite concentrations are initial values. (c) The effect of nitrite added to aerobic incubation mixtures $(2 \mathrm{ml})$ containing sodium succinate (50 mM) and $17 \mathrm{mg}$ (dry wt) of strain CB1809 bacteroids (- $)$ ) or CC705 bacteroids The vessels were shaken at $30^{\circ} \mathrm{C}$ for $30 \mathrm{~min}$.

\section{Effects of substrate concentration}

Succinate stimulated both nitrate reductase and $\mathrm{C}_{2} \mathrm{H}_{2}$ reduction at about $25 \mathrm{~mm}$, but higher concentrations were inhibitory (Fig. $3 a, b$ ). The effects of glucose concentration were quite different. Concentrations up to $\mathrm{I} 20 \mathrm{mM}$ stimulated $\mathrm{C}_{2} \mathrm{H}_{2}$ reduction and higher concentrations were inhibitory. However, glucose inhibited nitrate reduction at all concentrations used. The high optimum glucose concentration for $\mathrm{C}_{2} \mathrm{H}_{2}$ reduction and its different effect on the two reactions suggested that this sugar may be exerting an osmotic effect, 
Table I. Nitrogen fixation by bacteroid suspensions in aerobic and in anaerohic conditions (strain CC705)

Incubation mixtures ( $2 \mathrm{mi})$ in aerobic conditions contained: sodium-succinate (50 miv), bacteroids $25 \mathrm{mg}$ (dry wt) in phosphate buffer $(25 \mathrm{~mm}, \mathrm{pH} 74)$. In anaerobic conditions, the medium composition was: $\mathrm{KNO}_{3}(8 \mathrm{~mm})$, glucose $(0.1 \mathrm{M})$, bacteroids $50 \mathrm{mg}$ (dry wt) in phosphate buffer $\left(25 \mathrm{~mm}, \mathrm{pH} 74\right.$ ) for a final volume of $5 \mathrm{ml}$. The gas phase was: $\mathrm{N}_{2}, 68.6 \%\left({ }^{15} \mathrm{~N}, 87.6\right.$ atoms $\left.\%\right), \mathrm{A}$, $26.6 \%$ and $\mathrm{O}_{2} 4.8 \%$. Duplicate preparations were incubated for $30 \mathrm{~min}$ at $30 \mathrm{C}$ with shaking. For further details see text.

Preparations

Aerobically

Anaerobically
$\mathrm{NO}_{3}$

(mM)

o

* Includes carrier $\mathrm{NH}_{3}-\mathrm{N}$.

$$
\begin{gathered}
\mathrm{NH}_{3}-\mathrm{N} \\
\text { (/"g per vessel) }
\end{gathered}
$$

$47 \cdot 3$

$47 \cdot 3$

$55 \cdot 4$

$55 \cdot 4$

$45^{\circ} 0$
${ }^{15} \mathrm{~N}$ excess (atoms \%)

$2 \cdot 157$

$2 \cdot 006$

I. 602

$1 \cdot 565$

0.000
Fixed $\mathrm{NH}_{3}-\mathrm{N}$ (nnol $\mathrm{mg}^{-1}$ )

$$
\begin{aligned}
& 2 \cdot 92 \\
& 2 \cdot 7 \mathrm{I} \\
& I \cdot 27 \\
& 1 \cdot 24 \\
& 0.00
\end{aligned}
$$

similar to that of sucrose in aerobic assays (Bergersen \& Turner, 1967). The effect of glucose concentration was therefore tested in the presence of $15 \%$ and $30 \%(\mathrm{w} / \mathrm{v})$ dextran 40 (Pharmacia, Uppsala, Sweden). In these conditions, the optimum glucose concentration for $\mathrm{C}_{2} \mathrm{H}_{2}$ reduction was lower (Fig. $3 a, c$ ). In contrast, in aerobic assays, glucose did not stimulate $\mathrm{C}_{2} \mathrm{H}_{2}$ reduction by strain $\mathrm{CC}_{705}$ bacteroids. However, with succinate, slight stimulation of $\mathrm{C}_{2} \mathrm{H}_{2}$ reduction by glucose (up to about $50 \mathrm{~mm}$ ) was observed. Above $75 \mathrm{~mm}$, glucose was sharply inhibitory (Fig. 4): these concentrations ( 75 to $120 \mathrm{mM}$ ) stimulated anaerobic $\mathrm{C}_{2} \mathrm{H}_{2}$ reduction.

\section{The effect of nitrite}

Nitrite is a strong inhibitor of $\mathrm{C}_{2} \mathrm{H}_{2}$ reduction by bacteroids under both aerobic and anaerobic conditions. Fig. 5(a) shows that the rates of $\mathrm{C}_{2} \mathrm{H}_{2}$ reduction decrease as nitrite accumulates. Rates of $\mathrm{C}_{2} \mathrm{H}_{2}$ reduction, obtained by drawing tangents to the curves of Fig. I (a) at 10 and $20 \mathrm{~min}$, are plotted against nitrite concentration at those times. With" the exception of the point derived from the 10 min assay without additions, all points fall on a typical inhibition curve. Similar results were obtained when nitrite was added to anaerobic or aerobic assays (Fig. $5 b, c$ ). In the case of the anaerobic experiment the curve is flattened. This is due to the accumulation of nitrite from nitrate reduction; in Fig. 5(b) activities are plotted against the initial nitrite concentrations. In the curves of Fig. $5(a)$ and $(c) 50 \%$ inhibition was obtained at 0.5 to $0.8 \mathrm{~mm}$-nitrite. In the absence of added nitrite, concentrations of $2-3 \mathrm{~mm}$-nitrite were usual after $40 \mathrm{~min}$ in experiments with succinate as substrate (Fig. $1 b$ ).

$$
{ }^{15} \mathrm{~N}_{2} \text { experiments }
$$

All of the results described so far utilize $\mathrm{C}_{2} \mathrm{H}_{2}$ reduction as the assay for nitrogenase activity. Using ${ }^{15} \mathrm{~N}_{2}$ under anaerobic conditions with nitrate, glucose and $\mathrm{CC} 705$ bacteroids, I. $2 \mathrm{nmol}$ of $\mathrm{NH}_{3} / \mathrm{mg}$ of bacteroids was fixed in $30 \mathrm{~min}$ (Table I). Aerobically, with succinate as substrate, $2 \cdot 8 \mathrm{nmol} \mathrm{NH}_{3} / \mathrm{mg}$ was fixed. 


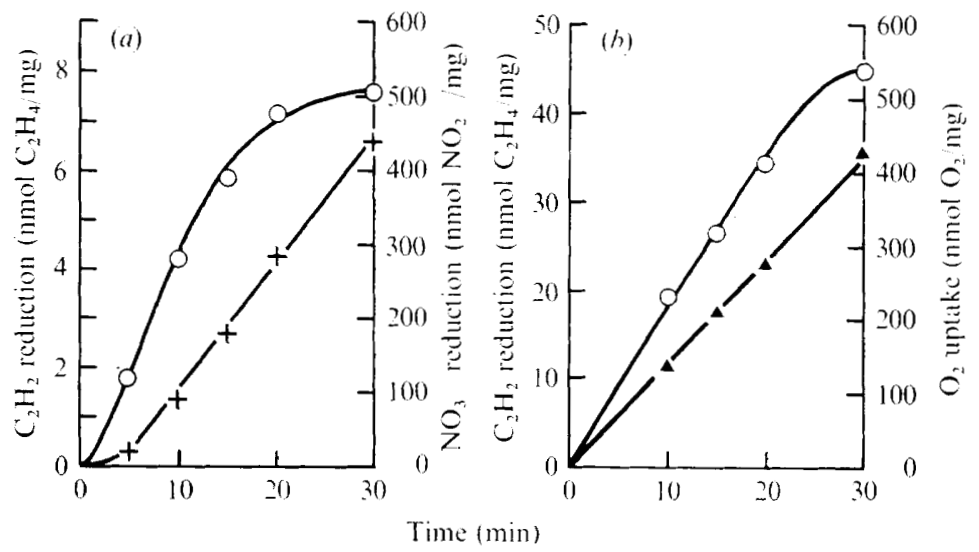

Fig. 6. Nitrate reduction and $\mathrm{O}_{2}$ uptake during the $\mathrm{C}_{2} \mathrm{H}_{2}$ reduction by bacteroid suspensions (cC705) in anaerobic $(a)$ and in aerobic $(b)$ conditions. All assays with sodium-succinate (25 mm) as substrate, shaking at $30^{\circ} \mathrm{C}$. Anaerobically, incubation mixtures $(5 \mathrm{ml})$ contained $\mathrm{KNO}_{3}(8 \mathrm{~mm})$, bacteroids (40 mg dry wt); $\mathrm{O}-\mathrm{O}, \mathrm{C}_{2} \mathrm{H}_{2}$ reduction; +- ++ , nitrate reduction. Aerobically, incubation mixtures $(2 \mathrm{ml})$ contained bacteroids $\left(2 \mathrm{mg}\right.$ dry wt); $\mathrm{O}-\mathrm{O}, \mathrm{C}_{2} \mathrm{H}_{2}$ reduction; $\Delta-\mathbf{\Delta}, \mathrm{O}_{2}$ uptake.

\section{Comparison of $\mathrm{O}_{2}$ and nitrate respiration}

In order to compare the relative efficiencies of $\mathrm{O}_{2}$ and nitrate respiration for the support of $\mathrm{C}_{2} \mathrm{H}_{2}$ reduction by bacteroids, experiments such as the one illustrated in Fig. 6 were conducted. Nitrite production was used to assay nitrate reduction since nitrite reduction was negligible (Daniel \& Appleby, 1972). Uptake of $\mathrm{O}_{2}$ was measured by analysis of the gas phase. In the experiment shown (Fig. 6), after $15 \mathrm{~min}$, when all reactions were proceeding linearly with time, $\mathrm{O}_{2}$-uptake and nitrate-reduction rates were the same ( $14 \mathrm{nmol} / \mathrm{min} / \mathrm{mg}$ ). However, the $\mathrm{C}_{2} \mathrm{H}_{2}$-reduction rate was $\mathrm{I} \cdot 85 \mathrm{nmol} \mathrm{C}_{2} \mathrm{H}_{4} / \mathrm{min} / \mathrm{mg}$, which was about 5 times higher than the anaerobic rate $\left(0.38 \mathrm{nmol} \mathrm{C}_{2} \mathrm{H}_{4} / \mathrm{min} / \mathrm{mg}\right)$. In terms of electrons transferred, the aerobic pathway was thus approximately 2.5 times as effective as the anaerobic pathway. This result is similar to that obtained in the ${ }^{15} \mathrm{~N}$ experiments (Table $\mathrm{I}$ ), where the ratio of the amounts of $\mathrm{NH}_{3}$ produced aerobically versus anaerobically was about $2 \cdot 3$, although the substrates were different in this experiment.

\section{DISCUSSION}

Soybean bacteroid nitrogenase requires ATP for activity (Koch, Evans \& Russel, 1967). The results presented above show that sufficient ATP is produced by anaerobic nitrate respiration to support nitrogenase activity in bacteroids which have an active nitrate reducing system. However, nitrate respiration is apparently 2.5 times less efficient than the aerobic pathway of respiration. The exact pathway(s) of terminal respiration in bacteroids is not known although the constituent haemoproteins (Appleby, 1969) and some of the other components have been described (Evans \& Russel, 1971).

The role of glucose as a substrate for bacteroids is uncertain. Burris \& Wilson (I939) found that glucose was a poor substrate for aerobic respiration by soybean bacteroids and this has been general experience since (see Bergersen, 1971). D. K. Kidby and C. A. Parker (private communication) have proposed that a glucose permease may be damaged during the preparation of bacteroids since enzymes for glucose metabolism are found in bacteroid 
extracts. The present results suggest that glucose may be utilized as an energy source by bacteroids, because $\mathrm{C}_{2} \mathrm{H}_{2}$ reduction is stimulated (Fig. I $a, 3 a, 4$ ). It is puzzling that glucose stimulates $\mathrm{C}_{2} \mathrm{H}_{2}$ reduction but not nitrate reduction. If it was being metabolized as a source of reducing power, glucose would be expected to stimulate both activities. Apparent osmotic effects concerned with the conservation of endogenous substrate have been reported previously for sucrose (Bergersen \& Turner, 1967). It is possible that glucose exerts a similar effect because the optimum glucose concentration for anaerobic $\mathrm{C}_{2} \mathrm{H}_{2}$ reduction is quite high ( $120 \mathrm{~mm}$, Fig. $3 a$ ) and is less in the presence of dextran (Fig. $3 c$ ) or when succinate is also present in aerobic assays (Fig. 4). This question would be resolved by a radiorespirometric study of glucose effects.

Inhibition by nitrite seemed to be superficially related to the different effects of glucose on $\mathrm{C}_{2} \mathrm{H}_{2}$ reduction and nitrate reduction. With glucose as substrate, nitrite production was always low and this seemed to allow higher rates of $\mathrm{C}_{2} \mathrm{H}_{2}$ reduction than with endogenous substrates. Fig. I (a) and $6(a)$ show the curved time course of nitrate-supported $\mathrm{C}_{2} \mathrm{H}_{2}$ reduction. In contrast, rates of $\mathrm{C}_{2} \mathrm{H}_{2}$ reduction under aerobic conditions were linear for $20 \mathrm{~min}$ (Fig. $6 b$ ). Also, Fig. I shows that succinate, which gave the highest rate of nitrate reduction, supported the briefest period of $\mathrm{C}_{2} \mathrm{H}_{2}$ reduction. These observations are consistent with the inhibitory effects of nitrite. However, other factors must also be involved in the declining rates because the changes in rates of $\mathrm{C}_{2} \mathrm{H}_{2}$ reduction between 20 and $30 \mathrm{~min}$ (Fig. $1 \mathrm{a}$ ) were not directly related to rates of nitrite accumulation in the assays. I. R. Kennedy (private communication) has observed inhibition by nitrite of nitrogenase in cell-free preparations from lupin bacteroids. The inhibitory effects of nitrite accumulating in the nodules of plants exposed to nitrate may explain in part the inhibitory effects of nitrate upon $\mathrm{N}_{2}$ fixation by legumes (Nutman, I956).

One of us (J.R.) was supported by a Scholarship from the North Atlantic Treaty Organization. The authors thank Miss P. Riddiford and Mr H. Tantala for technical assistance.

\section{REFERENCES}

APpleby, C. A. (1969). Electron transport systems of Rhizobium japonicum. II. Rhizobium haemoglobin, cytochromes and oxidases in free living (cultured) cells. Biochimica et biophysica acta $\mathbf{7 2}, 88-105$.

Bergersen, F. J. (I96I). Nitrate reductase in soybean root nodules. Biochimica et biophysica acta 52, $206-207$.

Bergersen, F. J. (1970). The quantitative relationship between nitrogen fixation and the acetylene-reduction assay. Australian Journal of Biological Sciences 23, $1015-1025$.

Bergersen, F. J. (1971). Biochemistry of symbiotic nitrogen fixation in legumes. Annual Review of Plant Physiology 22, I 2 I-I40.

Bergersen, F. J. \& Turner, G. L. (1967). Nitrogen fixation by the bacteroid fraction of breis of soybean root nodules. Biochimica et biophysica acta $\mathbf{1 4 1}, 507-515$.

Bergersen, F. J. \& TURner, G. L. (1968). Comparative studies of nitrogen fixation by soybean root nodules, bacteroid suspensions and cell free extracts. Journal of General Microbiology 53, 205-220.

Bergersen, F. J. \& TURner, G. L. (1970). Gel filtation of nitrogenase from soybean root nodule bacteroids. Biochimica et biophysica acta 214, 28-36.

Bergersen, F. J. \& Turner, G. L. (1973). Kinetic studies of nitrogenase from soybean root nodule bacteroids. Biochemical Joumal $\mathbf{1 3} \mathbf{1}, 6 \mathbf{1}-75$.

Burris, R. H. \& Wilson, P. W. (1939). Respiratory enzyme systems in symbiotic nitrogen fixation. Cold Spring Harbor Symposia for Quattitative Biology 7, 349-361.

Cheniae, G. \& Evans, H. J. (1960). Physiological studies on nodule nitrate reductase. Plant Physiology 35 , 454-462.

Daniel, R. M. \& Appleby, C. A. (1972). Anaerobic-nitrate, symbiotic and aerobic growth of Rhizobium japonicum: Effects on cytochrome $\mathrm{P} 450$, other haemoproteins, nitrate and nitrite reductases. Biochimica et biophysica acta 275, 347-354. 
Evans, H. J. \& Russel, S. A. (I971). Physiological chemistry of symbiotic nitrogen fixation by legumes. In The Chemistry and Biochemistry of Nitrogen Fixation, pp. 19I-244. Edited by J. R. Postgate. London: Plenum Press.

Hardy, R. W. F., Holsten, R. D., Jackson, E. K. \& Burns, R. C. (1968). The acetylene-ethylene assay for N-fixation: laboratory and field evaluation. Plant Physiology 43, I 185-1207.

Косн, B., Evans, H. J. \& Russel, S. (1967). Properties of the nitrogenase system in cell-free extracts of bacteroids from soybean root nodules. Proceedings of the National Academy of Sciences of the United States of America $\mathbf{5}^{\mathbf{8}, \mathrm{I}} 3 \mathbf{3 3}^{-\mathrm{I}} 35^{\circ}$.

MurPhy, S. G. \& ELKAN, G. H. (1965). Nitrogen metabolism of some strains of Rhizobium japonicum having different nodulating capacities. Canadian Journal of Microbiology II, I039-104I.

Nicholas, D. J. D. \& Nason, A. (1957). Determination of nitrate and nitrite. In Methods in Enzymology, vol. III, pp. 98I-984. Edited by S. P. Colowick and N. O. Kaplan. New York: Academic Press.

Nutman, P. S. (1956). The influence of the legume in root-nodule symbiosis. Biological Reviews 31, 109-151. 